Article

\title{
An Investigation into Energy Performance with the Integrated Usage of a Courtyard and Atrium
}

\author{
Tofigh Tabesh * and Begum Sertyesilisik* \\ Department of Architecture, Faculty of Architecture, Istanbul Technical University, Istanbul 34437, Turkey \\ * Correspondence: t.tabesh@gmail.com (T.T.); begum_sertyesilisik@hotmail.com (B.S.); \\ Tel.: +90-5395158546 (T.T.); +90-5324575723 (B.S.)
}

Academic Editor: Cinzia Buratti

Received: 25 January 2016; Accepted: 29 April 2016; Published: 17 May 2016

\begin{abstract}
Offices and retail spaces are among the most energy-intensive building typologies. Designing office buildings without proper consideration of their form, orientation, envelope, and other variables can lead to a considerable increase in energy usage. This research investigates how integrated usage of an atrium and courtyard can improve a building's energy performance. Thermal performance of both atrium and courtyard spaces as well as their energy-efficient integrated usage in office buildings have been investigated within the scope of this research. DesignBuilder as an interface and EnergyPlus (based on ASHRAE, the American Society of Heating, Refrigeration, and Air-Conditioning Engineers) as analytical software have been used to investigate the thermal behavior of an atrium and courtyard in two stages. From the results it appeared that a courtyard with $40 \%$ window-to-wall ratio and triple glazing has the best energy performance, while those with single glazing and an $80 \%$ window-to-wall ratio represent maximum energy consumption in all climates. The findings also revealed that the integrated usage of a courtyard and atrium can save energy if it is used as a courtyard type of building during summer in all climates and if it is used as an atrium in the cold months. This research is original and will contribute to the literature, as it investigates the integrated usage of an atrium and courtyard with respect to energy efficiency. This research is expected to be beneficial to professionals and academics, especially with respect to the energy-efficient use of courtyards, atria, and their integrated modes. Furthermore, the findings can contribute to the sustainability performance of the built environment through an integrated atrium-courtyard building, resulting in minimal energy consumption.
\end{abstract}

Keywords: courtyard; atrium; energy-efficient buildings; integrated design

\section{Introduction}

The energy efficiency of built environment in urban areas plays an important role in reducing the challenges of climate change, resource diminution, and wider environmental issues [1]. Building energy consumption level is expected to continue rising in the coming years [2]. Cai et al. (2009) stated that due to an improvement in living standards and rapid urbanization, there will be an increase in energy-consuming appliances (e.g., air conditioners) and urban building areas, which will further increase energy consumption [3]. For instance, Steemers (2003) highlighted that in the United Kingdom, buildings account for about half of all energy consumption, compared to $41 \%$ in Europe and $36 \%$ in the USA [1]. Offices rank second, just after retail buildings, as they consume $18 \%$ of the energy in the United States, 33\% in Spain, and 17\% in the United Kingdom [3]. Offices and retail spaces are among the most energy-intensive typologies in the non-domestic building sector as they account for over $50 \%$ of total energy consumption for non-domestic buildings [4]. Turkey's energy demand has increased by about $8 \%$ annually due to population increase and economic growth [5]. Turkey is an energy-importing country due to limited energy sources [6]. In recent years, energy imports accounted for more than 
$80 \%$ of the total primary energy supply in Turkey [7]. Within this composition, $99 \%$ of total gas demand, $93 \%$ of oil, and $55 \%$ of coal were imported from various countries [8]. Official figures project a continued increase in energy demand, with installed capacity expected to grow from 64 GW in 2014 to approximately $120 \mathrm{GW}$ in 2023 [9].

Recent work on the end-use of load characteristics of high-rise air-conditioned office buildings has revealed that air-conditioning and electric lighting account for $30 \%-60 \%$ and $20 \%-35 \%$ of total building electricity consumption, respectively [10]. The annual energy consumption in European office buildings varies from 100 to $1000 \mathrm{kWh} / \mathrm{m}^{2}$ of conditioned floor space, depending on location, construction, HVAC and lighting installations, use and type of office equipment, operating schedules, etc. [11]. There is a need to consider passive design options (e.g., building form, orientation, and envelope) more carefully and to enhance indoor air quality by energy-efficient means.

The incorporation of an atrium into commercial buildings can save energy by providing good daylight, natural ventilation, and a buffer zone between the indoor and outdoor environment. However, the large glazing surfaces of an atrium absorb excessive solar heat in the summer and lose heat in the winter. Atria and courtyards can be extremely effective at providing daylight and additional heat to adjacent spaces and in reducing transmission losses. The thermal performance of courtyard/atrium buildings depends greatly on factors (such as geometry, location, latitude, height, external climate, microclimate, etc.) that involve working with the climate rather than against it so that the need for artificial space conditioning is reduced [12]. For instance, in this research three climates of Turkey—mild/humid, cold, and hot/dry—have been taken into account. A mild/humid climate has high humidity, fog, cold winters, and low average temperatures, with a mild and often wet spring and autumn [13]. Istanbul has been selected as the representative city for the mild/humid climate. A cold climate has very cold winters with high annual snowfall. Erzurum has been selected as the representative city for the cold climate [13]. A hot/dry climate is characterized by high temperatures and high solar radiation. Diyarbakir has been selected as the representative city for the hot/dry climate [13].

There have been various studies done on courtyard and atrium design. None of these studies, however, considered energy-efficient and integrated use of atria and courtyard. There is a gap in the literature with respect to research into improving energy performance with the integrated usage of atria and courtyards. This is supported by Perez-Lombard et al. (2008), who recommend further analysis of the energy demand of non-domestic buildings such as office buildings. The current research is significant as it fills these gaps in the literature [14]. This research investigates how integrated usage of an atrium and courtyard can improve a building's energy performance with respect to seasonal effects and climate factors.

\section{Literature Review}

Energy efficiency is becoming more of a priority in recent years because energy consumption is becoming a crisis [15]. The commercial buildings sector consumes a huge amount of energy and its energy consumption pattern will likely increase sharply in the near future [16]. As a result, there has been a general movement towards finding effective design strategies to reduce the energy demands of buildings and encourage further awareness of energy-conscious design [17]. Gratia and Herde (2003) have stressed that passive solar energy can reduce the auxiliary heating costs in office buildings without compromising occupant comfort [18].

All aspects of the atria and courtyards in buildings (i.e., their proportion, orientation, shape and size, height, shading control, glazing type and ratio, and the thermal mass of walls) need to be carefully considered in the design phase. Poor or inappropriate design may create challenges in controlling temperature, glare, and energy consumption [19].

Most atrium and courtyard buildings depend on mechanical systems for cooling or heating throughout the year and do not take advantage of the atrium and courtyard as a tool to minimize energy consumption. Causes of dependence on mechanical systems to maintain a proper comfort level 
within the structure include: incorporation of atria and courtyards that are vastly less efficient than the nominal case [20], and miscalculation of the importance of controlling the factors determining the courtyard or atrium's energy efficiency (i.e., orientation, size or ratio of atrium or courtyard to adjacent spaces, envelope constructions, and type and function of atrium or courtyard) [21]. Similarly, Atif (1994) mentioned a lack of design tools for optimizing the energy consumption in an atrium and emphasized the need for an integrated design considering all aspects of the atrium (i.e., acoustics, smoke control management, etc.) [22]. Mills (1991) stated that the problem in designing atrium buildings was the lack of available definitive guidance; most architects tend to look towards example projects for inspiration or learn through trial and error [23]. Furthermore, Mills (1991) noted that with the help of correct atrium design, the building can capture solar energy to reduce the building's energy consumption while also creating a comfortable and visually pleasant environment [23].

There are various studies on the energy performance of the courtyards. The research mainly focused on the shape, ventilation, and energy performance of the courtyards. The main studies are briefly summarized in the following:

- Studies on the shape of courtyards: Several studies were carried out on the optimum size of courtyards, whether circular, polygon, rectangular, or square, in different climates, locations, and latitudes. Muhaisen and Gadi (2005) showed that shallow courtyards perform better than deeper ones [15]. Muhaisen and Gadi (2006a) found that deep courtyards require less energy for cooling in summer [24]. Muhaisen and Gadi (2006b) stressed that in polygon models deep courtyard forms of any shape are recommended to achieve maximum internal shaded areas in summer. However, in winter, shallow forms were desirable for obtaining sunlit areas [25]. Muhaisen (2006)'s research revealed that the optimum courtyard height to obtain reasonable performance in summer and winter is three-story in a hot, humid climate; two-story in hot, dry, and temperate climates; and one-story in a cold climate [26]. Kocagil and Oral (2015) studied four commonly seen reference standardized plan types of traditional courtyard in Diyarbakir, representative of a hot, dry climate in Turkey. They showed that the inner courtyard plan with a total surface area to total volume (A/V) ratio of 0.50 consumed $63 \%$ less heating energy and $79 \%$ less cooling energy than the L-type plan with an A/V ratio of 1.00 [27]. Manioglu and Oral (2015) studied courtyard shape, varying the ratio of courtyard width (W) to courtyard length (L) to reduce heating and cooling loads. In this study Diyarbakir was selected as a representative city of hot, dry climate in Turkey. They found that $\mathrm{W} / \mathrm{L}$ ratios that require little energy for cooling can result in high heat loads and thus more need for heating [28].

- Studies on the ventilation of courtyards: Horan and Finn (2008)'s study revealed that there is no clear relationship between the proportion of ventilation areas opened and the atrium air change rate [29]. Yasa and Ok (2008)'s study revealed that openings in vertical surfaces increase the speed of air flow inside courtyards. They also indicated that openings located on perpendicular surfaces increase the velocities of airflows within courtyards in proportion to their dimensions and positions [30]. Yasa and Ok (2014)'s research on the energy performances of courtyard shapes in Diyarbakır, Antalya, and Erzurum (as representative cities for hot/dry, hot/humid, and cold climates in Turkey, respectively) revealed that during warm periods, a square courtyard was the optimum choice for all three regions in terms of inter-courtyard thermal gain [31].

There have been various studies on the energy performance of atria. These studies can be classified based on their focus with respect to shape, stack effect, ventilation, and climate conditions.

- Studies on atrium shape: Laouadi et al. (2002)'s research on the thermal and energy performance of atria in cold climates revealed that pyramidal/pitched skylights increased the solar heat gain up to $25 \%$ in winter for enclosed and linear atria, and up to $10 \%$ for a three-sided atrium compared to a flat skylight, whereas the skylight shape did not significantly affect the solar heat gain in the summer [32]. Galasiu and Atif (2002)'s research on the thermal parameters of an atrium building 
in Ottawa revealed that the solar heat gains resulted in significant temperature stratification of about $5{ }^{\circ} \mathrm{C}$ between the top and bottom floors [33]. Aldawoud (2013)'s study indicated that thermal performance of square and rectangular atria differ according to climate type, glazing type, and ratio of atrium length to width. Furthermore, this study highlighted that the total energy consumption of a narrow, elongated atrium or a rectangular atrium with high ratio of length to width is significantly more than that of a square atrium [19]. Assadi et al. (2011)'s research revealed that glass height and atrium diameter had a significant impact on the total absorption area of incident solar radiation [9]. Haw et al. (2012)'s research on a full-scale experimental building with a venturi-shaped wind-induced ventilation tower inMalaysia revealed that a venturi-shaped roof tower can generate an air flow rate eight times greater than normal cross-ventilation in a hot, humid climate. Furthermore, their study revealed that the aerodynamic performance of the venturi-shaped roof of the wind-induced natural ventilation tower can produce the low pressure required to induce fresh air from outdoor into indoor spaces of the building [34].

- Studies on the stack effect in an atrium: Lin and Chuah (2011)'s study on the stack effect of natural ventilation in three cities (Taipei, Taichung, and Kaohsiung) in Taiwan revealed that for a large space of above $6 \mathrm{~m}$ in height, an opening ratio greater than $0.9 \%$ can satisfy the required fresh air rate [35]. Liu et al. (2009)'s research on the performance of buoyancy-driven ventilation in atrium buildings during the design stage revealed that the size of the stack openings located in an atrium roof affect the temperature distribution in the atrium space and that the stack opening's position can create direct ventilation paths, which can be helpful in improving the internal thermal environment. The research also revealed that due to the small temperature difference in hot and humid climates, a buoyancy-only ventilation strategy is not very effective [36].

- Studies on ventilation of an atrium: Karava et al. (2012) evaluated night cooling strategies for heat removal from concrete (thermal mass) floor slabs. The investigation showed that an inflowing air stream at lower temperatures has increased cooling capacity and that indoor temperature in the atrium depends on solar radiation [37]. Woods et al. (2009)'s study revealed that in order to mitigate temperature contrasts of several degrees in an atrium, the ventilation rates between the different floors and the atrium should have independent controls, so that the rates may be varied in response to the measurements of the local atrium temperatures within the surrounding building [38]. Gocer (2006) studied the thermal performance simulation of an atrium office building in Istanbul. He concluded that an atrium must be designed as a part of the energy strategy of the building [39].

- Studies on the effects of climate on the atrium's energy performance: Abdullah et al. (2009) investigated the application of two low-cost measures, namely high level internal solar blinds and water spray, on the three levels inside the atrium of a guesthouse in southern China [40]. They indicated that in hot, humid tropical climates, a partially air-conditioned, three-level, top-glazed atrium would suffer high temperature stratification on the top floor, causing great discomfort to the occupants [40]. Their study revealed that the two solar gain control measures contributed to the improvement of thermal conditions inside the atrium [40]. Laouadi and Atif (1998) worked on developing skylight design tools for thermal and energy performance of atria in cold climates [41]. They compared the computed and measured thermal parameters in an atrium building [41]. Aldawoud and Clark (2006) analyzed the energy performance of atria and courtyards and revealed that open courtyards were more energy efficient for lower buildings. Their study revealed that by increasing a building's height, the 'enclosed atrium' became more energy efficient. [19].

The literature review revealed that studies have been focused on the energy performance of either atria or courtyards (Table 1). There is a gap in the literature with respect to the energy-efficient, integrated usage of an atrium and courtyard so that the energy performance of the office building can be improved by considering seasons and climate factors. This research aims to fill this gap in the literature. 
Table 1. List of the analyzed literature on the energy performance of atria/courtyards.

\begin{tabular}{|c|c|c|}
\hline $\begin{array}{l}\text { Authors and } \\
\text { Publication Years }\end{array}$ & Research Topic & $\begin{array}{l}\text { Topic Covered in the } \\
\text { Research (Atrium } \\
\text { or Courtyard) }\end{array}$ \\
\hline $\begin{array}{l}\text { Laouadi et al. } \\
\text { (2002) [32] }\end{array}$ & $\begin{array}{c}\text { Towards developing skylight design tools for thermal and energy } \\
\text { performance of atriums in cold climates }\end{array}$ & Atrium \\
\hline $\begin{array}{l}\text { Laouadi, and Atif } \\
\quad(1998)[41]\end{array}$ & $\begin{array}{l}\text { Comparison between computed and field measured thermal parameters } \\
\text { in an atrium building }\end{array}$ & Atrium \\
\hline $\begin{array}{l}\text { Galasiu and Atif } \\
\quad(2002)[33]\end{array}$ & $\begin{array}{l}\text { Applicability of daylighting computer modeling in real case studies: } \\
\text { Comparison between measured and simulated daylight availability and } \\
\text { lighting consumption }\end{array}$ & Atrium \\
\hline $\begin{array}{l}\text { Luis and Perez-Garci } \\
\text { (2004) [42] }\end{array}$ & Parametric study of solar gains in saw-tooth roofs & Courtyard \\
\hline $\begin{array}{l}\text { Muhaisen and Gadi } \\
\text { (2005) [15] }\end{array}$ & $\begin{array}{l}\text { Mathematical model for calculating the shaded and sunlit areas in } \\
\text { a circular courtyard geometry }\end{array}$ & Courtyard \\
\hline $\begin{array}{l}\text { Muhaisen and Gadi } \\
\text { (2006a) [24] }\end{array}$ & $\begin{array}{l}\text { Using computer tool (IES) to investigate the effect of solar heat gain on } \\
\text { the energy demand of a courtyard }\end{array}$ & Courtyard \\
\hline $\begin{array}{l}\text { Muhaisen and Gadi } \\
\text { (2006b) [25] }\end{array}$ & Shading performance of a polygonal courtyard & Courtyard \\
\hline Muhaisen (2006) [26] & Shading simulation of the courtyard form in different climatic regions & Courtyard \\
\hline $\begin{array}{l}\text { Aldawoud and Clark } \\
\quad(2006)[43]\end{array}$ & $\begin{array}{c}\text { Computer simulation analyzed energy performance of atria } \\
\text { and courtyards }\end{array}$ & Atrium \\
\hline $\begin{array}{l}\text { Horan and Finn } \\
\quad(2008)[29]\end{array}$ & Sensitivity of air change rates in a naturally ventilated atrium & Atrium \\
\hline Liu et al. (2009) [36] & Evaluation of buoyancy-driven ventilation in atrium & Atrium \\
\hline Woods et al. (2009) [38] & $\begin{array}{l}\text { Comparison of winter pre-heating requirements for natural displacement } \\
\text { and natural mixing ventilation }\end{array}$ & Atrium \\
\hline $\begin{array}{l}\text { Abdullah et al. } \\
\text { (2009) [40] }\end{array}$ & Field study on indoor thermal environment in an atrium & Atrium \\
\hline $\begin{array}{l}\text { Kim and Tai Kim } \\
\text { (2010) [44] }\end{array}$ & Luminous impact of balcony floor at atrium spaces & Atrium \\
\hline Enes Yasa (2008) [31] & $\begin{array}{l}\text { Effects of surface openings on air flow caused by wind in } \\
\text { courtyard buildings }\end{array}$ & Courtyard \\
\hline $\begin{array}{l}\text { Du and Sharples } \\
\text { (2011) [45] }\end{array}$ & $\begin{array}{l}\text { Assessing and predicting average daylight factors of adjoining spaces } \\
\text { in atrium }\end{array}$ & Atrium \\
\hline Assadi et al. (2011) [8] & $\begin{array}{l}\text { Analytical model of atrium for heating and ventilating } \\
\text { an institutional building }\end{array}$ & Atrium \\
\hline $\begin{array}{l}\text { Lin and Chuah } \\
\text { (2011) [35] }\end{array}$ & $\begin{array}{l}\text { Study on the potential of natural ventilation and cooling for large spaces } \\
\text { in subtropical climatic regions }\end{array}$ & Atrium \\
\hline Karava et al. (2012) [37] & $\begin{array}{l}\text { Experimental study of the thermal performance of a large institutional } \\
\text { building with mixed-mode cooling and hybrid ventilation. }\end{array}$ & Atrium \\
\hline Haw et al. (2012) [34] & Empirical study of wind-induced natural ventilation & Atrium \\
\hline $\begin{array}{c}\text { Al-Masri and } \\
\text { Abu-Hijleh (2012) [46] }\end{array}$ & An environmental assessment of the courtyard & Courtyard \\
\hline Aldawoud (2013) [19] & The influence of the atrium geometry on the building energy performance & Atrium \\
\hline Cantón et al. (2014) [47] & $\begin{array}{l}\text { Courtyards as a passive strategy in semi-dry areas. Assessment of } \\
\text { summer energy and thermal conditions in a refurbished school building. }\end{array}$ & Courtyard \\
\hline Yaşa and Ok (2014) [30] & $\begin{array}{l}\text { Evaluation of the effects of courtyard building shapes on solar heat gains } \\
\text { and energy efficiency according to different climatic regions. }\end{array}$ & Courtyard \\
\hline $\begin{array}{l}\text { Kocagil and Oral } \\
\quad \text { (2015) [27] }\end{array}$ & $\begin{array}{l}\text { The effect of building form and settlement texture on energy efficiency for } \\
\text { hot, dry climate zone in Turkey }\end{array}$ & Courtyard \\
\hline $\begin{array}{l}\text { Manioğlu and Oral } \\
\text { (2015) [28] }\end{array}$ & $\begin{array}{l}\text { Effect of courtyard shape factor on heating and cooling energy loads in } \\
\text { hot, dry climatic zone }\end{array}$ & Courtyard \\
\hline
\end{tabular}

Modeling energy usage of buildings is an important step towards designing and implementing policy measures related to energy savings in buildings. Simulation of buildings' thermal performances 
is necessary to predict occupants' comfort in buildings and to identify alternate mechanical control systems for achieving better indoor thermal environments.

\section{Research Methods}

This research aims to identify the energy-efficient integrated usage of an atrium and courtyard so that the energy performance of the office buildings can be improved by considering seasons and climate factors. The research objectives can be listed as follows:

- Studying the effect of glazing type on energy consumption of atria and courtyards as well as of their integrated usage.

- Investigation of energy performance of the courtyard and atrium buildings to find an optimum integrated solution.

- This research is planned to answer to the following research question:

How can we integrate atrium and courtyard usage to increase the energy efficiency of the buildings?

Research aims and objectives as well as the research methods applied for each objective are summarized in Table 2.

Table 2. Aims, objectives, and research methods.

\begin{tabular}{|c|c|c|}
\hline Aim & Objectives & Research Methods \\
\hline \multirow{3}{*}{$\begin{array}{l}\text { Energy-efficient } \\
\text { integrated usage of } \\
\text { atrium and courtyard }\end{array}$} & $\begin{array}{l}\text { Objective 1: Studying the effect of } \\
\text { glazing type on energy consumption of } \\
\text { considered buildings }\end{array}$ & $\begin{array}{l}\text { Using DesignBuilder software as } \\
\text { an interface for modeling and } \\
\text { EnergyPlus as calculation software }\end{array}$ \\
\hline & $\begin{array}{l}\text { Objective 2: Studying the effect of } \\
\text { window-to-wall ratio on energy } \\
\text { conservation of courtyard and atrium }\end{array}$ & $\begin{array}{l}\text { Using DesignBuilder software as } \\
\text { an interface for modeling building and } \\
\text { EnergyPlus as calculation software }\end{array}$ \\
\hline & $\begin{array}{l}\text { Objective 3: Find an optimum integrated } \\
\text { solution from the time viewpoint for } \\
\text { courtyard and atrium }\end{array}$ & $\begin{array}{l}\text { Comparison of the results helps with } \\
\text { finding the optimum seasonal usage of } \\
\text { both atrium and courtyard }\end{array}$ \\
\hline
\end{tabular}

The analyses have been carried out applying two main building energy performance simulation tools, namely EnergyPlus (Version 8.1) and DesignBuilder (Version 4.2.0.054):

- EnergyPlus has been used for calculating heating, cooling, lighting, ventilating, and other energy flows. EnergyPlus is reliable as it has been validated under the comparative Standard Method of Test for the Evaluation of Building Energy Analysis Computer Programs BESTEST/ASHRAE STD 140 [48].

- DesignBuilder, as the GUI (Graphical Usage Interface) for EnergyPlus, is the most comprehensive interface for EnergyPlus available today. It includes a simplified CAD interface, templates, wizards, and the compact air system configurations of EnergyPlus. DesignBuilder has been used to evaluate façade options, and to analyze thermal simulation, daylighting, total energy consumption, $\mathrm{CO}_{2}$ reduction, natural ventilation, and sizing of HVAC equipment and systems [49].

Building energy simulation provides a quick and easy estimate of the energy consumption in a given building, based on the corresponding climate and building characteristics. Some popular building energy simulators are EnergyPlus and DOE-2 [50]. EnergyPlus is a whole-building energy simulation software, which allows users to model complex mechanical heating and cooling, lighting, and ventilation systems in detail. The software allows for user-specified time increments, permitting sub-hourly analysis of building and energy systems as well as a wealth of output data reporting options. Today the most restricting limitation of EnergyPlus is the missing graphical user interface that provides all EnergyPlus capabilities [51]. 
Besides eQUEST and several other graphical user interfaces, DesignBuilder is one of the most advanced user interfaces, and provides several usability enhancements to the EnergyPlus simulation engine.

DesignBuilder provides a variety of country- or region-specific templates for selection of parameters (such as materials and constructions). Lists of other definable parameters include internal loads (with occupancy patterns/activities), construction types, openings (windows and doors), lighting, and HVAC systems. The typical usage of DesignBuilder includes evaluation of façade options, daylighting analysis, visualization of site layouts and solar shading, thermal simulation of natural ventilation, and sizing of HVAC equipment and systems [49].

The accuracy of the DesignBuilder software has been validated using the BESTest (Building Energy Simulation TEST) procedure, originally developed by the International Energy Agency. The BESTest is a comparative set of tests that has been regarded by the American Department of Energy and the international community as being a reputable basis for evaluating the capabilities of building energy simulation programs [52].

\subsection{Energy Simulation Parameters}

The growing complexity of buildings in function and design has made whole-building energy performance simulation an integral part of the planning process for building services engineers. It has three key phases: modeling, simulation, and results analysis. In the modeling phase, a baseline-building model has been generated. In the simulation phase, performance of simulations over a specified time and climate has been evaluated and the energy consumption profiles of the office building systems have been computed. In the results analysis phase, the results of the simulation have been presented to the user.

The thermal behavior of two office buildings (one having a central, enclosed atrium with a skylight and the other having a central courtyard) has been modeled and analyzed. The thermal performance of both atrium and courtyard spaces as well as their integrated usage have been analyzed. DesignBuilder as an interface and EnergyPlus (based on ASHRAE) as an analytical software will be used to find the thermal behavior of the atrium and courtyard with regard to climatic variables, different glazing type, and glazing area ratios as well as different numbers of floors.

The variables investigated in this study were: weather and climate zone, shape of the courtyard, building height, building depth, $\mathrm{U}$ values of the construction layers, glazing types, and window-to-wall ratio. These variables are explained in the following paragraphs:

\subsection{Weather and Climate Zone}

The climate influences the energy and environmental performance of a building. Climate affects buildings, and subsequently the comfort of the occupants. Each climate presents its own unique challenges for energy-efficient building design. The impact of the three climates of Turkey, namely cold (Erzurum), mild and humid (Istanbul) and hot and dry (Diyarbakir) on the energy performance of models and their alternatives have been investigated. For each climate type a representative city has been selected in the simulation process.

- Low and unpredictable precipitation is the primary characteristic of a hot, dry climate. Hot, dry weather in summer, cold in winter, very little rainfall, very low humidity, and a high temperature difference between night and day are the characteristics of this climate [13]. In this research Diyarbakir is considered representative of the hot, dry climate of Turkey during the simulation stages. The average monthly relative humidity and temperature in Diyarbakir are shown in Table 3 [53].

- According to Köppen-Geiger classifications, a mild, humid climate is typified by large seasonal temperature differences, a subtropical climate with no dry season, and consistent moisture. Summers are hot and muggy with thunderstorms. Winters are mild with precipitation. 
Seasonality is moderate. Precipitation is usually well distributed through the year [13]. Istanbul was considered representative of a mild, humid climate in this research. The average monthly relative humidity and temperature in Istanbul are shown in Table 4 [53].

- Erzurum is the characteristic city for cold climate. According to Köppen-Geiger classifications, Erzurum has a humid continental climate with severe winters, no dry season, warm summers, and strong seasonality [13]. The average monthly relative humidity and temperature in Erzurum are shown in Table 5 [53].

Table 3. Monthly average relative humidity and average temperature in Diyarbakir (adapted from [53]).

\begin{tabular}{ccccccccccccc}
\hline Diyarbakir & Jan. & Feb. & Mar. & Apr. & May & June & July & Aug. & Sep. & Oct. & Nov. & Dec. \\
\hline Humidity & $74 \%$ & $68 \%$ & $66 \%$ & $64 \%$ & $55 \%$ & $34 \%$ & $24 \%$ & $25 \%$ & $34 \%$ & $50 \%$ & $60 \%$ & $79 \%$ \\
Min $\left({ }^{\circ} \mathrm{C}\right)$ & -2 & -1 & 2 & 7 & 11 & 16 & 22 & 21 & 16 & 10 & 4 & 0 \\
Max $\left({ }^{\circ} \mathrm{C}\right)$ & 7 & 9 & 14 & 20 & 27 & 33 & 38 & 38 & 33 & 25 & 16 & 9 \\
\hline
\end{tabular}

Table 4. Monthly average relative humidity and average temperature in Istanbul (adapted from [53]).

\begin{tabular}{ccccccccccccc}
\hline Istanbul & Jan. & Feb. & Mar. & Apr. & May & June & July & Aug. & Sep. & Oct. & Nov. & Dec. \\
\hline Humidity & $79 \%$ & $76 \%$ & $75 \%$ & $74 \%$ & $74 \%$ & $70 \%$ & $71 \%$ & $74 \%$ & $75 \%$ & $80 \%$ & $79 \%$ & $80 \%$ \\
Min $\left({ }^{\circ} \mathrm{C}\right)$ & 3 & 2 & 3 & 7 & 12 & 16 & 18 & 19 & 16 & 13 & 9 & 5 \\
$\operatorname{Max}\left({ }^{\circ} \mathrm{C}\right)$ & 8 & 9 & 11 & 16 & 21 & 25 & 28 & 28 & 24 & 20 & 15 & 11 \\
\hline
\end{tabular}

Table 5. Monthly average relative humidity and average temperature in Erzurum (adapted from [53]).

\begin{tabular}{ccccccccccccc}
\hline Erzurum & Jan. & Feb. & Mar. & Apr. & May & June & July & Aug. & Sep. & Oct. & Nov. & Dec. \\
\hline Humidity & $78 \%$ & $77 \%$ & $75 \%$ & $67 \%$ & $63 \%$ & $59 \%$ & $54 \%$ & $51 \%$ & $54 \%$ & $66 \%$ & $75 \%$ & $79 \%$ \\
Min $\left({ }^{\circ} \mathrm{C}\right)$ & -13 & -12 & -7 & 0 & 5 & 8 & 11 & 11 & 7 & 2 & -3 & -10 \\
$\operatorname{Max}\left({ }^{\circ} \mathrm{C}\right)$ & -4 & -3 & 2 & 11 & 17 & 21 & 26 & 27 & 22 & 15 & 7 & -1 \\
\hline
\end{tabular}

\subsection{Shape of the Courtyard}

The courtyard models have been designed based on the criteria obtained from the literature survey. Courtyard thermal performance is mainly affected by the solar radiation penetration of the internal envelope, which is dependent on the courtyard geometrical parameters and the sun's position $[15,24,25]$. Shading and exposure conditions on the internal envelope of the courtyard are affected by rectangular courtyard proportions [26]. By considering the elongation of the courtyard form (a rectangular courtyard width/its length), it appeared that a square courtyard is optimum in terms of energy demand [26]. Yasa and Ok (2014) highlighted that during the summer a square courtyard shows better energy performance in the three climate regions of Turkey. As a result, to achieve energy-efficient building in this study the courtyard is modeled as a square [30].

\subsection{Building Height}

From the literature survey it appeared that shallow courtyards perform better than deeper ones during winter; however, courtyards having deep forms require low energy for cooling in summer $[15,24,25]$. With regard to the achievement of an optimum height for courtyard building, Muhaisen (2006) suggested three stories in hot, humid climates, two stories in hot, dry, and temperate climates, and one story in a cold climate [26].

Considering alternatives such as R1 (floor perimeters P/form's height H) and R2 (elongation of the form L/its length $\mathrm{W}$ ) that affect a rectangular courtyard's shape and height when the height of each story is set at $3.30 \mathrm{~m}$ (floor to floor), the side of the square courtyard for two and three stories are calculated at around $8 \mathrm{~m}$ and $25 \mathrm{~m}$, respectively. (DesignBuilder measures the height of the last story at more than $3.3 \mathrm{~m}$ due to having characteristics of a roof layer.) In this research a courtyard building 
is considered to have three stories because of providing architectural aspect, outside view, and more natural light for adjacent buildings.

\subsection{Depth of the Surrounding Building}

The depth depends upon the functional requirements and size of the floor plate and is a very important consideration for interior planning as well as for the entire courtyard building configuration. Considering the daylight in courtyard building performance, there is a need to concentrate on the depths of the surrounding building in tall building design because the quantity and quality of daylight can be determined by the depth of the surrounding building. Shpuza (2006) considered four types of building characterized by the depth of the space: very deep (over $20 \mathrm{~m}$ deep), deep (11-19 $\mathrm{m}$ deep), medium (6-10 $\mathrm{m}$ deep), and shallow (4-5 $\mathrm{m}$ deep) [43]. According to the Ko et al. (2008), the depth of the building should usually be between 10 and $14 \mathrm{~m}$ for office functions [54]. Cho (2007) also highlighted that $80 \%$ of high-rise buildings use a space depth of 10 to $15 \mathrm{~m}$ [55] . The maximum allowable depth of space in Germany is typically about $5.5 \mathrm{~m}$, whereas in the United States as much as $15 \mathrm{~m}$ is no rarity [54]. Therefore, based on the collected depth of space range data mentioned above, office types having a depth of $10 \mathrm{~m}$ have been considered and simulated in this research.

\subsection{Description of the Construction Layers}

Since the building envelope was a critical component in the simulation process, this study investigated glazing for the courtyard walls and the atrium skylight for both base models and their alternatives. Table 6 and Figure 1 show the description of the construction layers and the area. The U-values have been selected in accordance with Turkish standard "Thermal insulation requirements for buildings" (TS 825) [56] as the reference cities were chosen from Turkey. The selected U-values are provided in Table 6.

Table 6. U-values of construction for the reference cities in the research (Turkish Standard, 2014 [56]).

\begin{tabular}{cccc}
\hline U-Value $\left(\mathbf{W} / \mathbf{m}^{\mathbf{2}} \mathbf{K}\right)$ & Istanbul & Diyarbakir & Erzurum \\
\hline External wall & 0.45 & 0.45 & 0.40 \\
Roof & 0.40 & 0.40 & 0.25 \\
Floor & 0.30 & 0.30 & 0.40 \\
Windows & 2.4 & 2.4 & 2.4 \\
\hline
\end{tabular}

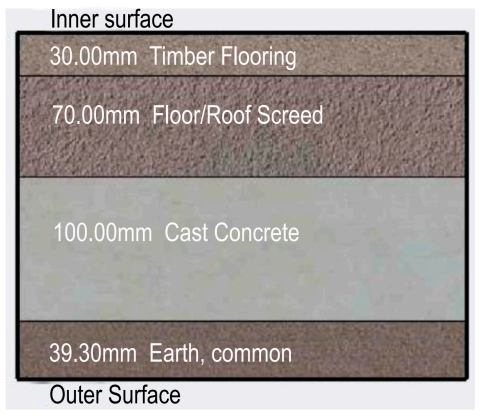

(a)

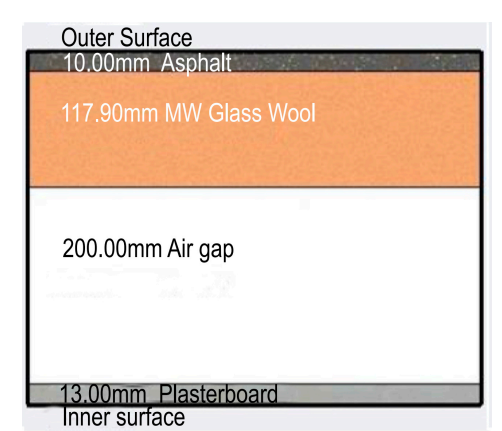

(b)

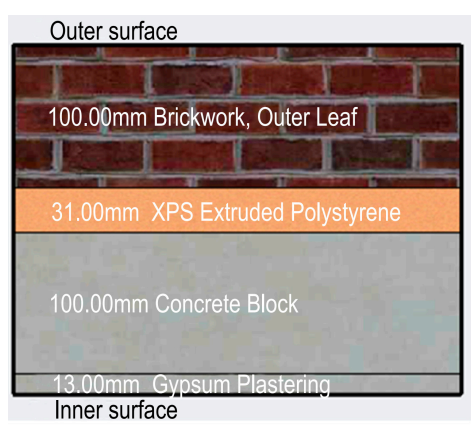

(c)

Figure 1. Construction details and layers of (a) ground floor; (b) external roof; and (c) external wall.

\subsection{Glazing System}

Single, double, and triple glazing have been investigated for the models. Selected clear glazing types for the courtyard walls as well as the atrium skylight are as follows (Table 7): 
- Single glazing: a single pane of glass with low thermal properties compared with other glazing types.

- Double glazing: ordinary double glazing, which consists of two layers of glass filled with air.

- Triple glazing: triple panes of glass filled with air.

Table 7. Characteristics of glazing types (adapted from the data taken from DesignBuilder).

\begin{tabular}{cccc}
\hline $\begin{array}{c}\text { Characteristics of } \\
\text { Glazing Types }\end{array}$ & $\begin{array}{c}\text { Single Clear, } \\
\mathbf{6 ~} \mathbf{~ m m}\end{array}$ & $\begin{array}{c}\text { Double Clear, Each Pan: } \\
\mathbf{6} \mathbf{~ m m} \text { with Air } \mathbf{6 ~} \mathbf{~ m m}\end{array}$ & $\begin{array}{c}\text { Triple Clear, Each Pan: } \\
\mathbf{3} \mathbf{~ m m} \text { with Air } \mathbf{~} \mathbf{~ m m}\end{array}$ \\
\hline Total solar transmission (SHGC) & 0.819 & 0.7 & 0.682 \\
Direct solar transmission & 0.775 & 0.604 & 0.595 \\
Light transmission & 0.881 & 0.781 & 0.738 \\
U-Value $\left(\mathrm{W} / \mathrm{m}^{2} \mathrm{~K}\right)$ & 5.778 & 3.094 & 2.178 \\
\hline
\end{tabular}

\subsection{Window Area and Properties}

Courtyard and atrium buildings, which have been simulated in this research, have been considered to have a constant $30 \%$ window-to-wall ratio on the external facade of the building. The ratio of glazing to walls in courtyard and atrium areas of buildings is set at $40 \%, 60 \%$, and $80 \%$ to study the energy performance of the adjacent area of courtyard and atrium.

\subsection{General Model Descriptions}

This study examined the influence of glazing type on window-to-wall ratios in different climates, namely hot and dry, mild and humid, and cold climates, for the proposed model of courtyard building. In order to reach the aforementioned goal, an open central courtyard surrounded by adjacent spaces was modeled in DesignBuilder. In terms of investigation, three-story square courtyards were modeled. The central courtyard area was $625 \mathrm{~m}^{2}$ ( $25 \mathrm{~m}$ length and $25 \mathrm{~m}$ width). In the adjacent spaces floor height was $3.50 \mathrm{~m}$ and the depth of the office area was designed to be $10 \mathrm{~m}$ (Figure 2). The internal environment of the four office spaces was modeled as fully air-conditioned. The area of the office building was considered to be $1400 \mathrm{~m}^{2}$ for each floor and the total area in the three stories was measured at $4200 \mathrm{~m}^{2}$. Table 8 provides possible parameters from the literature review regarding the design of courtyard and atrium forms. Figure 3 shows the process of simulation in this research, which is divided in two stages. The first stage tries to illustrate the feasibility of a variety of window-to-wall ratios and different glazing types as applied to courtyard walls. The second stage attempts to model an energy-efficient building by covering a courtyard and shifting it to the atrium type to conserve energy.

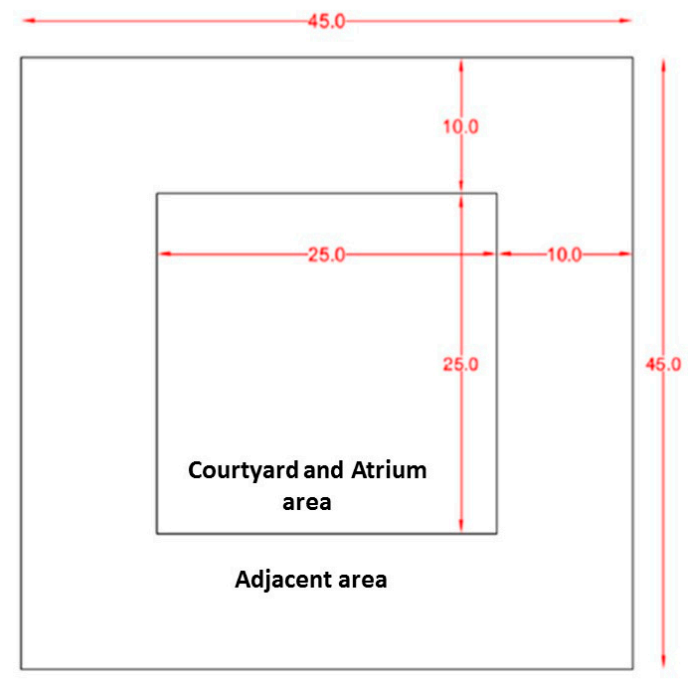

Figure 2. Dimensions of courtyard and atrium plan. 
Table 8. Parameters for courtyard and atrium design.

\begin{tabular}{|c|c|c|c|}
\hline $\begin{array}{l}\text { Criteria Obtained from } \\
\text { Literature Review }\end{array}$ & Alternatives & Author (Year) & Best Possible Parameter \\
\hline Shape for courtyard & $\begin{array}{c}\text { Rectangular } \\
\mathrm{R} 1 \text { = floor perimeters } \mathrm{P} / \text { form's height } \mathrm{H} \\
\mathrm{R} 2 \text { = elongation of the form } \mathrm{L} / \text { its length } \mathrm{W}\end{array}$ & $\begin{array}{l}\text { Muhaisen and Gadi (2006a) (courtyard) } \\
\text { Climate [24] }\end{array}$ & $\begin{array}{c}\text { Energy demand of } \mathrm{R} 1=5,6,7,8,9,10 \\
\text { are very close to each other } \\
\mathrm{R} 1=1,2,3,4 \text { have no architectural aspect } \\
\mathrm{R} 1=5 \text { is optimum } \\
\mathrm{R} 2=1,2,3,4 \text { have no architectural aspect } \\
\text { Energy demand of } \mathrm{R} 1=5,6,7,8,9,10 \\
\text { are very close to each other } \\
\mathrm{R} 2=7 \text { is optimum (tend to be a square) }\end{array}$ \\
\hline Shape for atrium & Square & Aldawoud (2013) [19] (atrium) & $\begin{array}{c}\text { (Square shape) length } \times \text { width }= \\
1.0 \times 1.0 \text { is optimum }\end{array}$ \\
\hline Window-to-wall ratio & Various window-to-wall ratios & $\begin{array}{l}\text { Aldawoud and Clark (2006) [57] } \\
\text { (courtyard and atrium) }\end{array}$ & $40 \%, 60 \%$, and $80 \%$ \\
\hline Climate & Different climate and longitude & Muhaisen (2006) [26] (courtyard) & $\begin{array}{l}\text { hot and dry (Diyarbakir), cold } \\
\text { (Erzurum), temperate (Istanbul) }\end{array}$ \\
\hline Number of floors & Different heights & Al-Masri and Abu-Hijleh (2012) [46] & three stories \\
\hline Type of glazing & Various types & Al-Masri and Abu-Hijleh (2012) [46] & single, double, triple \\
\hline Type of HVAC & Various types & DesignBuilder types & compact type \\
\hline
\end{tabular}



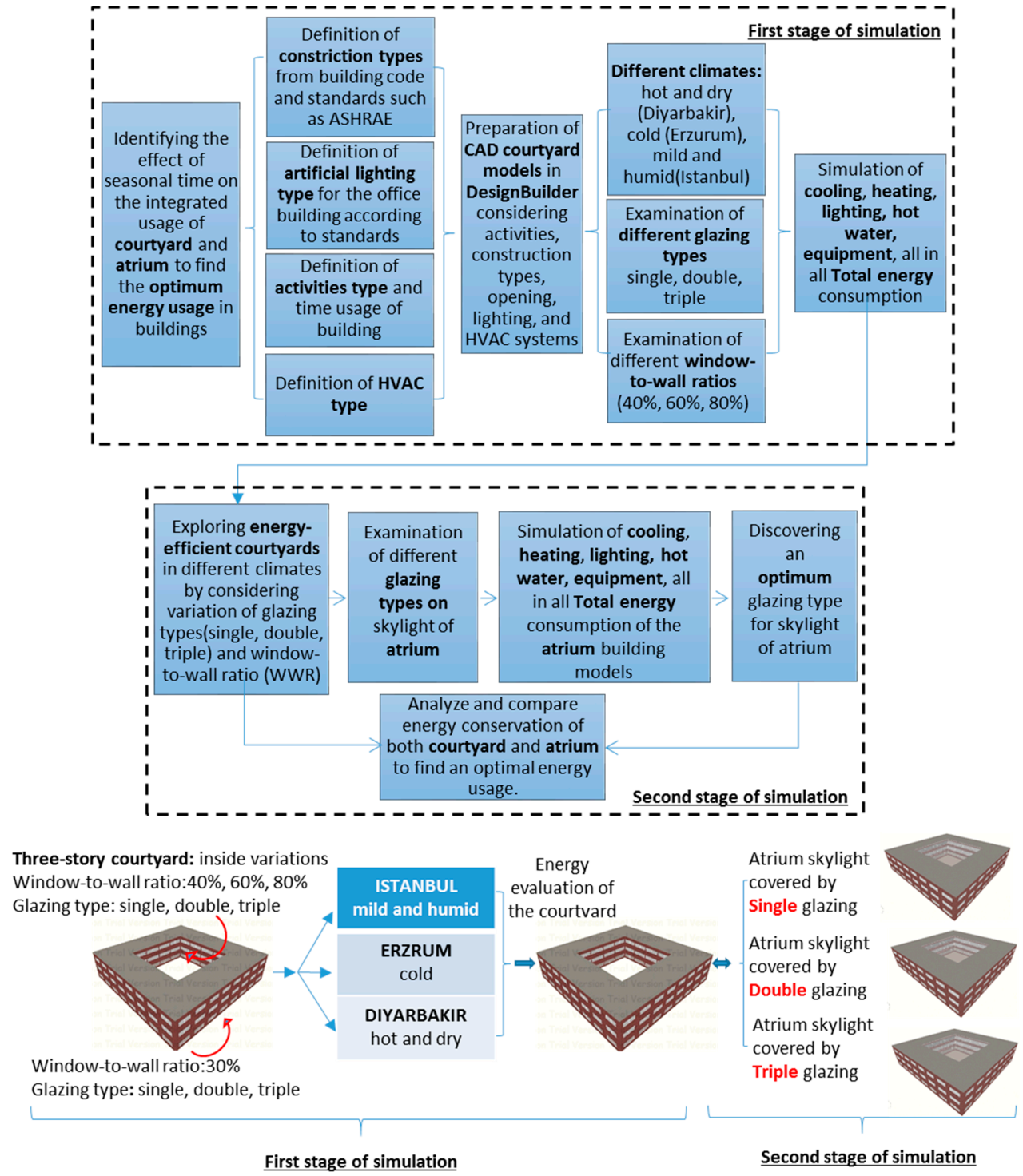

Figure 3. Two stages of the simulation process.

\section{Results}

\subsection{First Stage Simulation Results}

The first stage of the simulation process has been applied to three-story courtyard building models in Istanbul, Erzurum, and Diyarbakir, which are representative cities for mild and humid, cold, and hot climates, respectively. A courtyard building can reduce the energy demand by replacing single glazing with double and triple glazing in all regions. From the outcomes, it appears that a single-glazed courtyard has the worse results while a triple-glazed courtyard shows better performance at all window-to-wall ratios in the considered climates. As Figure 4 shows, a courtyard building that has $40 \%$ window-to-wall ratio and triple glazing has the best performance while those with single glazing and $80 \%$ window-to-wall ratio require the maximum energy consumption in all climates. Moreover, the maximum energy requirement for a modeled building occurs in Istanbul, while Erzurum has the minimum energy demand.

In this simulation, the courtyard, which had single glazing, has been taken as the base model for the comparison of energy consumption of a courtyard building with double and triple windowpanes. Figure 5 illustrates the percentage of heating, cooling, and lighting energy conserved 
by different window-to-wall ratios in the three climates investigated. Accordingly, triple glazing with an average of $27 \%$ and double glazing with an average of $20 \%$ energy conservation show better performance for heating energy demand in comparison to a courtyard building with single glazing. Furthermore, a rising window- to-wall ratio in courtyards' inside walls means an increased energy savings on heating in the three climates investigated due to collected solar radiation energy. By varying the window-to-wall ratio from $40 \%$ to $80 \%$ in all regions, the energy savings on cooling decreases. Figure 5 highlights that the most energy saving on cooling occurs in Diyarbakir, whereas in Erzurum minimum cooling energy conservation has been observed. With the increase in window-to-wall ratio in courtyard inside walls covered by double and triple glazing, lighting energy saving increases, in the three investigated cities.

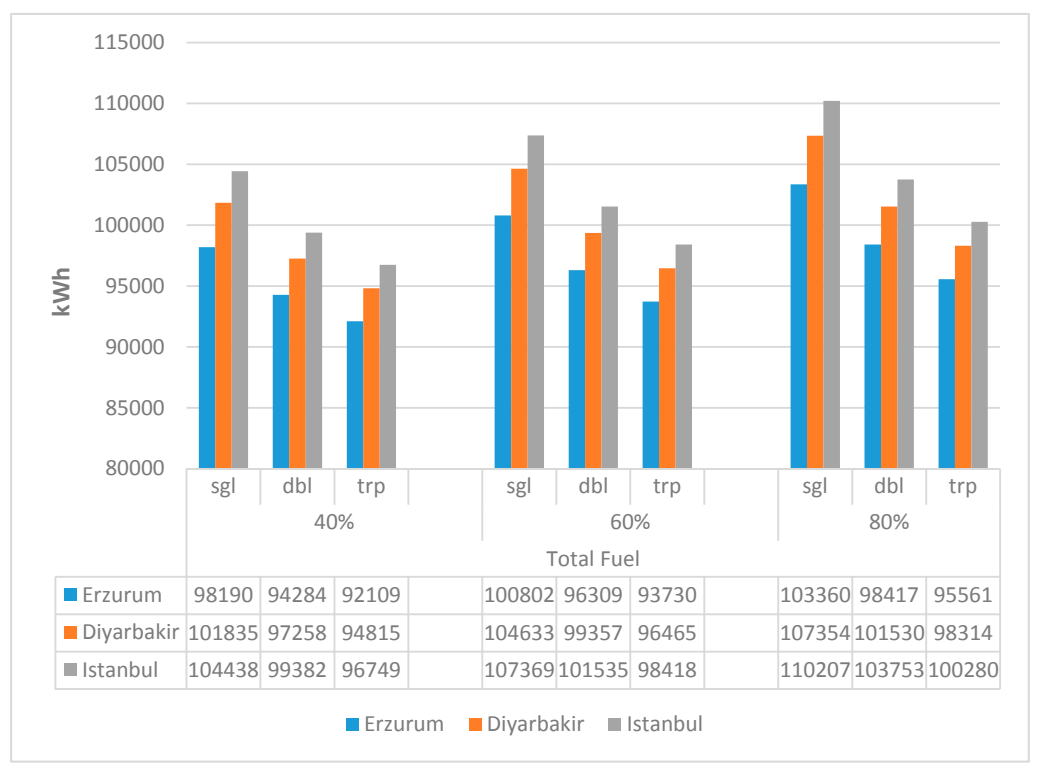

Figure 4. Total heating, cooling and lighting energy consumption for different window-to-wall ratios in Istanbul, Erzurum, and Diyarbakir (kWh).

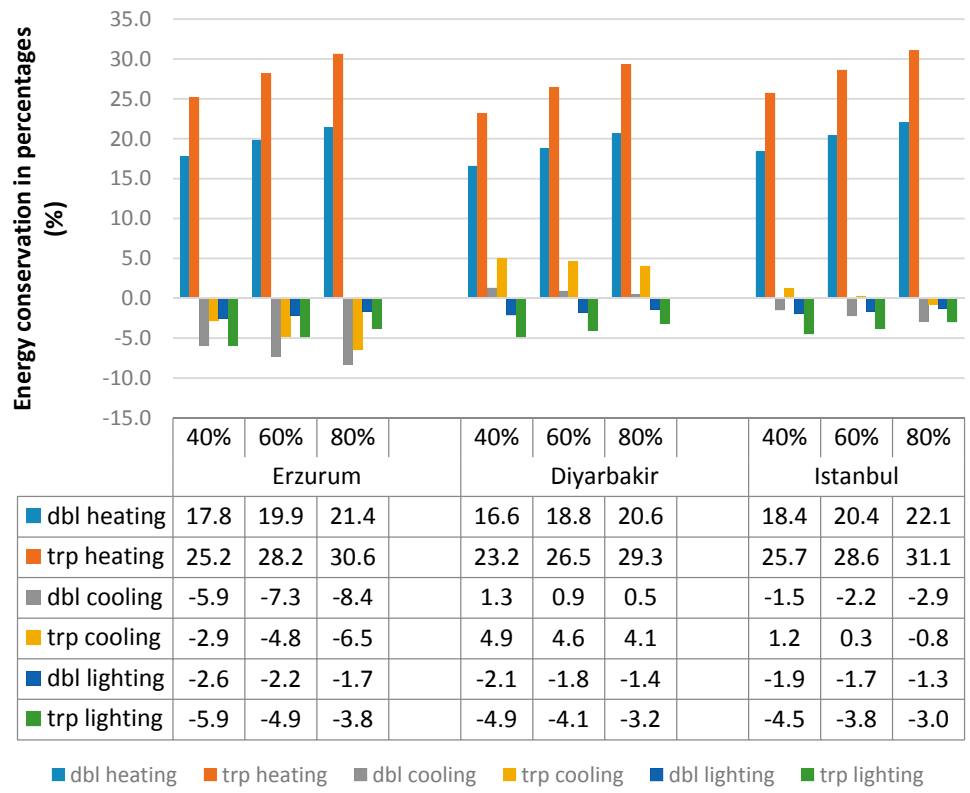

Figure 5. Cooling, heating, and lighting energy conservation in percentages (when double or triple glazing replaces single glazing in different window-to-wall ratios in Erzurum, Diyarbakir, and Istanbul). 


\subsection{Second Stage Simulation Results}

A courtyard model having triple glazing on its walls and a window-to-wall ratio of $40 \%$ on inside walls and $30 \%$ on outside walls is compared with three types of atrium using the same glazing type and window-to-wall ratio (Figure 6). Different glazing types (single, double, and triple) have been examined for an atrium skylight in order to choose the proper type for the parent building from an energy consumption point of view.
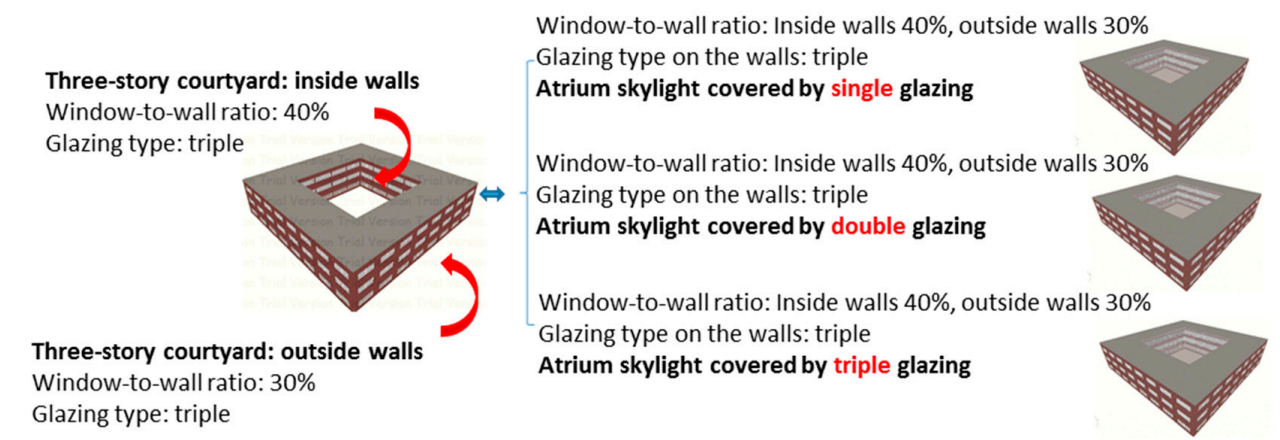

Figure 6. Comparison of the energy performance of a courtyard with three different types of atrium (taking the glazing type and window-to-wall ratio as constant) covered with different glazing types (single, double, or triple) as the second stage of simulation process.

\subsubsection{Istanbul}

In Figure 7, the zero line is considered to be the courtyard energy performance of a reference building for comparing three atrium buildings covered with single, double, and triple glazing.

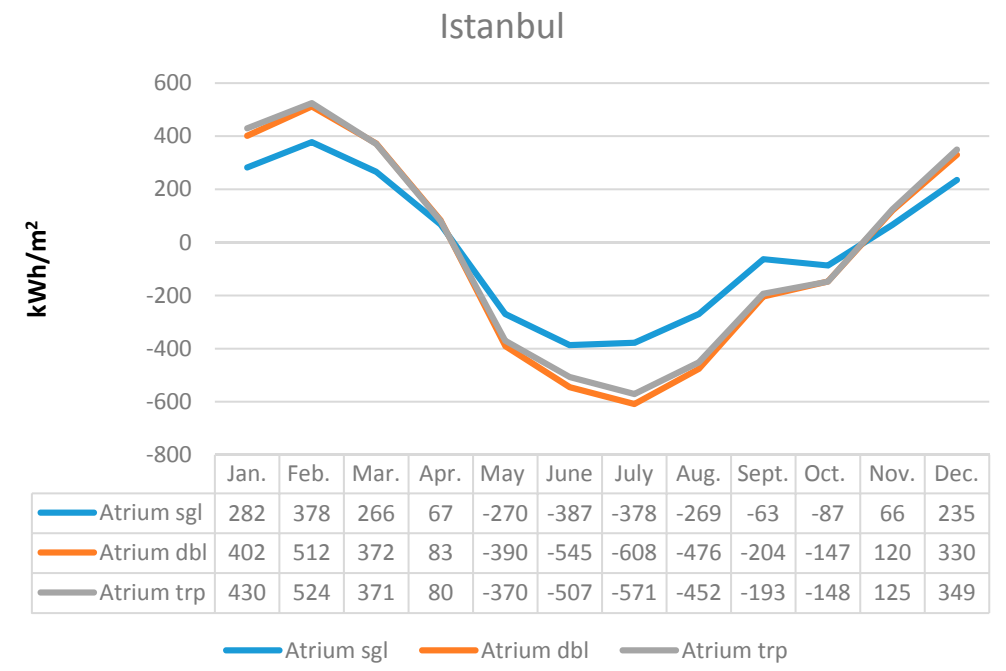

Figure 7. Monthly energy conservation of an atrium model with different type of glazing (single, double, and triple) on top of the atrium building in comparison to the courtyard (taken as the zero line) in Istanbul $\left(\mathrm{kWh} / \mathrm{m}^{2}\right)$.

Simulation outcomes reveal that in Istanbul an atrium building can conserve energy, starting from November for all single, double, and triple glazing and lasting until April. The amount of energy saved varied, however, by glazing type. It also appeared that a skylight with either triple or double glazing can perform better than single glazing. The most energy savings in atriums $\left(377.7 \mathrm{kWh} / \mathrm{m}^{2}\right)$ is observed in February, by using single glazing on top of the atrium and 511.9 and $524.5 \mathrm{kWh} / \mathrm{m}^{2}$ for 
double and triple glazing, respectively. During the warm period from May until October atrium types use more energy compared to a courtyard.

Comparing atriums roofed with triple, double and single glazing maximum energy consumption, 571,608 and $387 \mathrm{kWh} / \mathrm{m}^{2}$ respectively with courtyard in July-means that the courtyard shows better performance than an atrium during warm periods. This is due to the greenhouse effect of an atrium covered by various types of glazing.

\subsubsection{Erzurum}

In Figure 8, the zero line is considered to be the courtyard energy performance of a reference building to be compared with three atrium buildings covered with single, double, and triple glazing.

Outcomes reveal that, like in Istanbul, both triple and double glazing can perform better than single glazing in Erzurum (Figure 8). Unlike Istanbul, the most energy savings in atria occurred in March. Using single, double, and triple glazing on top of the atrium can conserve total energy by 288,554 and $596 \mathrm{kWh} / \mathrm{m}^{2}$, respectively, compared to a courtyard. During the warm period from May until September, atria use more energy compared with a courtyard. Atria roofed with single, double, and triple glazing used 642,906 , and $887 \mathrm{kWh} / \mathrm{m}^{2}$ more energy, respectively, in July compared to a courtyard. This means that in Erzurum, like in Istanbul, a courtyard shows better performance than an atrium during warm periods.

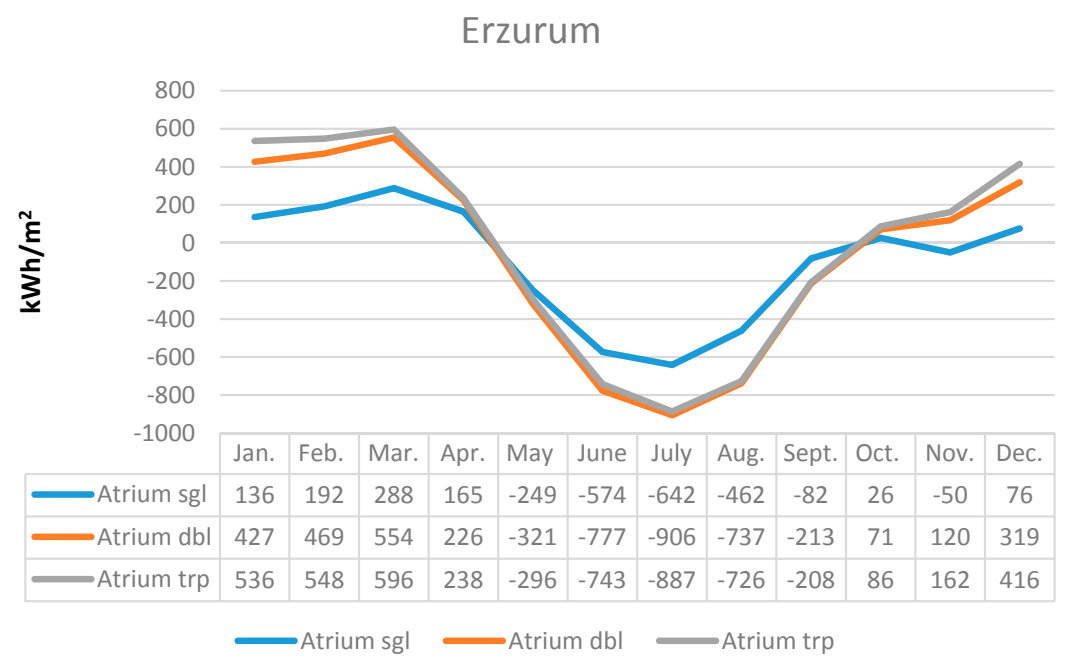

Figure 8. Monthly energy conservation of an atrium model with different type of glazing (single, double, and triple) on top of the atrium building in comparison to the courtyard (taken as the zero line) in Erzurum $\left(\mathrm{kWh} / \mathrm{m}^{2}\right)$.

\subsubsection{Diyarbakir}

Simulations revealed that, in Diyarbakir, the duration for using covered atriums to save energy is shorter than the duration needed in both Istanbul and Erzurum (Figure 9). In Diyarbakir a courtyard shows better performance than an atrium from April until August. Atria use more energy compared to a courtyard model from mid-April until July. The maximum energy waste was observed for atria with double and triple glazing in June ( 445 and $497 \mathrm{kWh} / \mathrm{m}^{2}$, respectively, compared to $334 \mathrm{kWh} / \mathrm{m}^{2}$ for a single-glazed atrium in May). Like in Istanbul and Erzurum, in Diyarbakir during the winter all atria show better performance compared to a courtyard. Maximum energy savings was observed in January for single-, double-, and triple-glazed atria compared to a courtyard-by 141, 244 and $261 \mathrm{kWh} / \mathrm{m}^{2}$, respectively. 


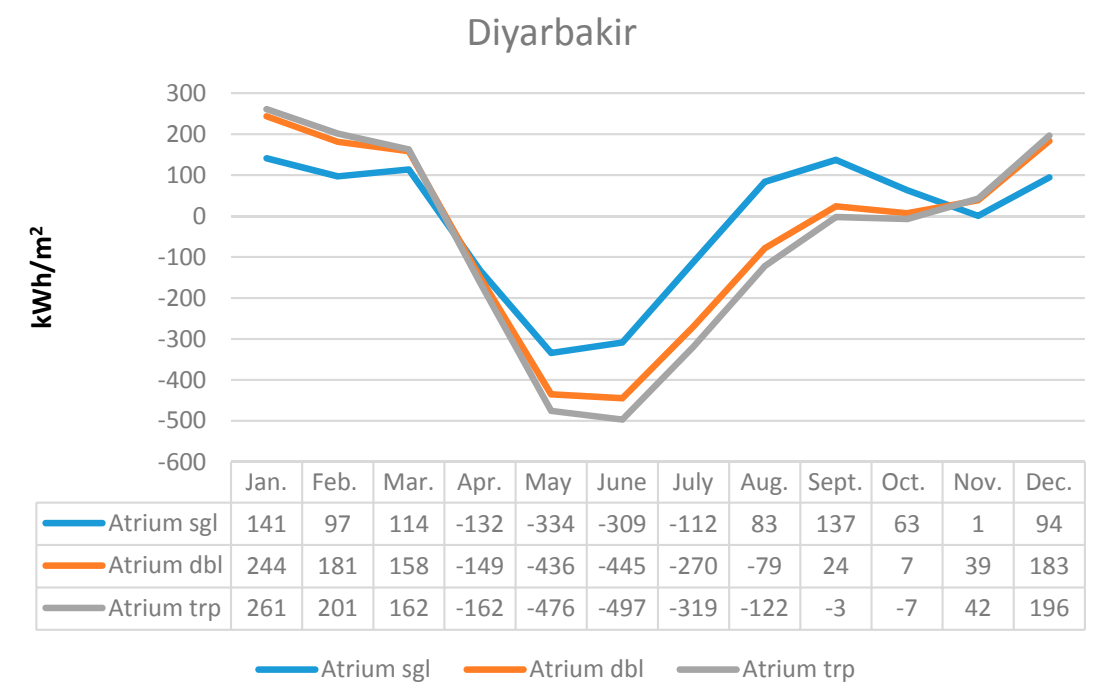

Figure 9. Monthly energy conservation of atrium model with different types of glazing (single, double, and triple) on top of the atrium building in comparison to a courtyard (taken as the zero line) in Diyarbakir $\left(\mathrm{kWh} / \mathrm{m}^{2}\right)$.

In the literature, there is a lack of a comprehensive strategy in terms of courtyards' and atriums' integrated usage with respect to their thermal performance under different conditions. Various studies indicated that the characteristics of both building types affect the indoor environment conditions $[12,19,22,40,41]$. The thermal behavior of courtyard and atrium buildings, as well as their integrated usage with respect to climatic variables (e.g., cold, hot and dry, or mild and humid), different glazing types, and glazing area ratios have been analyzed within the scope of this research. The results revealed that glazing types should be selected to minimize energy consumption so that occupant comfort is enhanced and daylight effectiveness is maximized while meeting architectural objectives. Sizing windows should be kept within acceptable limits. Simulation results revealed that considering the glazing type when covering a courtyard (single, double, or triple) can conserve energy (Table 9).

Table 9. Using integrated, energy-conscious courtyard or atrium buildings according to time.

\begin{tabular}{cccc}
\hline & \multicolumn{3}{c}{ Courtyard Is More Energy Efficient Compared to the Atrium } \\
\hline $\begin{array}{c}\text { City } \\
\text { Usage period }\end{array}$ & $\begin{array}{c}\text { Istanbul (mild and humid) } \\
\text { May until mid-Oct. }\end{array}$ & $\begin{array}{c}\text { Erzurum (cold) } \\
\text { May until mid-Sept. }\end{array}$ & $\begin{array}{c}\text { Diyarbakir (hot and dry) } \\
\text { Apr. until Aug. }\end{array}$ \\
\hline & \multicolumn{2}{c}{ Atrium Is More Energy Efficient Compared to the Courtyard } \\
\hline City & Istanbul (mild and humid) & Erzurum (cold) & Diyarbakir (hot and dry) \\
Single glazing on skylight & Nov. until Apr. & Oct. until Apr. & Apr. until July \\
Double glazing on skylight & Nov. until Apr. & Oct. until Apr. & Sept. until 15th Mar. \\
Triple glazing on skylight & Nov. until Apr. & Oct. until Apr. & Oct. until 15th Mar. \\
\hline
\end{tabular}

\section{Discussion}

The first step simulations have been carried out taking into account three different climates, namely cold (Erzurum), mild and humid (Istanbul), and hot (Diyarbakir). The simulation model has been prepared in the DesignBuilder using the following criteria: construction, artificial lighting, activity, and HVAC type as well as time usage of building from standards such as ASHRAE and Turkish Standards, CAD file of courtyard models. Furthermore, different WWR $(40 \%, 60 \%$, and $80 \%)$ have been examined for different glazing types. Simulation results for cooling, heating, lighting, and total energy consumption of the courtyard building have been evaluated to find the optimum integrated usage of a courtyard and atrium with respect to energy efficiency. The results revealed that glazing ratios have a significant impact on the total energy consumption of a courtyard building. 
Total energy conservation occurs at the same WWR (40\%) for single, double, or triple glazing of a three-story courtyard. Energy saving for heating occurs by replacing single glazing with triple in all three investigated climates for the courtyard model. Results showed that increasing WWR from $40 \%$ to $80 \%$ caused a reduction in the cooling energy conservation in all investigated climates. Increasing WWR decreases lighting energy demand in all studied cities.

The second step simulations have been carried out to identify the effect of seasonal time on the energy efficiency of the integrated usage of a courtyard and atrium. The simulation has been based on a courtyard model that had $40 \%$ WWR and triple glazing (as an optimum energy need form of courtyard for all regions), covered by a skylight with single, double, or triple glazing. The aforementioned different glazing types have been examined for an atrium skylight to determine the proper glazing type with respect to energy consumption for the parent building. Simulation results revealed that considering the glazing type (single, double, or triple) when covering a courtyard can conserve energy in cold months in all climate regions. However, the amount of energy savings differs with respect to climate conditions and glazing types. The highest total energy conservation happened in the simulation model where an atrium skylight was covered by triple glazing for all regions in cold months. Double glazing showed a similar performance to triple glazing. On the other hand, covering an atrium area with single glazing provided lower performance compared to the two other glazing types. Simulations for an atrium covered by triple glazing in Erzurum (as a representative of cold climates) provided the maximum total energy savings in March, $596 \mathrm{kWh} / \mathrm{m}^{2}$. The simulations have revealed that the most energy savings was observed in February $\left(524 \mathrm{kWh} / \mathrm{m}^{2}\right)$ for Istanbul and in January $\left(261 \mathrm{kWh} / \mathrm{m}^{2}\right)$ for Diyarbakir. During the summer, however, using an atrium instead of a courtyard increased the total energy consumption in Erzurum, Istanbul, and Diyarbakir (887, 571, and $497 \mathrm{kWh} / \mathrm{m}^{2}$, respectively).

\section{Conclusions}

This research aimed to identify the energy-efficient, integrated usage of an atrium and courtyard so that energy performance for office buildings can be improved with respect to seasonal and climate factors. With this aim, simulations have been carried out in two steps. The first step simulations were carried out by exploring energy-efficient courtyards in different climates by considering various glazing types (single, double, or triple) and window-to-wall ratios (WWR). The second step simulations have been carried out to identify the effect of seasonal time on the energy efficiency of the integrated usage of a courtyard and atrium.

The findings revealed that the integrated usage of a courtyard and atrium can save energy in all three climates if a courtyard mode/strategy is adopted during the summer and an atrium architectural mode is used in the cold months. The results of this research showed that using the passive characteristics of courtyards, atria, and, most importantly, their integrated usage influences energy consumption. Since a number of alternatives appear to impact on building energy consumption, further studies are recommended to be carried out on the energy performance impacts of the integration of other passive energy strategies (e.g., the stack effect) on buildings.

Acknowledgments: This research has been supported by the ITU Scientific Researches Unit (Project ID: 37750).

Author Contributions: Tofigh Tabesh and Begum Sertyesilisik have worked together in this research and contributed to the paper.

Conflicts of Interest: The authors declare no conflict of interest.

\section{References}

1. Steemers, K. Energy and the city: Density, buildings and transport. Energy Build. 2003, 35, 3-14. [CrossRef]

2. Feng, Y.-P.; Wu, Y.; Liu, C.-B. Energy-efficiency supervision systems for energy management in large public buildings: Necessary choice for china. Energy Policy 2009, 37, 2060-2065. 
3. Cai, W.; Wu, Y.; Zhong, Y.; Ren, H. China building energy consumption: Situation, challenges and corresponding measures. Energy Policy 2009, 37, 2054-2059. [CrossRef]

4. U.S. Energy Information Administration. International Energy Statistics Database and Short-Term Outlook. Available online: http:/ / www.Eia.Gov (accessed on 9 September 2014).

5. Çapik, M.; Yılmaz, A.O.; Çavuşoğlu, İ. Present situation and potential role of renewable energy in turkey. Renew. Energy 2012, 46, 1-13. [CrossRef]

6. Gökmen, A.; Temiz, D. The importance and impact of fossil and renewable energy sources in turkey on business and the economy. Energy Sources Part B Econ. Plan. Policy 2015, 10, 14-20. [CrossRef]

7. Akpınar, A.; Kömürcü, M.İ.; Kankal, M.; Özölçer, İ.H.; Kaygusuz, K. Energy situation and renewables in turkey and environmental effects of energy use. Renew. Sustain. Energy Rev. 2008, 12, 2013-2039. [CrossRef]

8. Assadi, M.K.; Dalir, F.; Hamidi, A.A. Analytical model of atrium for heating and ventilating an institutional building naturally. Energy Build. 2011, 43, 2595-2601. [CrossRef]

9. U.S. Energy Information Administration. International Energy Data and Analysis. Available online: https: / / www.Eia.Gov/beta/international/analysis.Cfm?Iso=tur (accessed on 30 July 2015).

10. Lam, J.C.; Li, D.H.; Cheung, S. An analysis of electricity end-use in air-conditioned office buildings in hong kong. Build. Environ. 2003, 38, 493-498. [CrossRef]

11. Caccavelli, D.; Gugerli, H. Tobus-A european diagnosis and decision-making tool for office building upgrading. Energy Build. 2002, 34, 113-119. [CrossRef]

12. Aldawoud, A. Thermal performance of courtyard buildings. Energy Build. 2008, 40, 906-910. [CrossRef]

13. Kottek, M.; Grieser, J.; Beck, C.; Rudolf, B.; Rubel, F. World map of the köppen-geiger climate classification updated. Meteorol. Z. 2006, 15, 259-263. [CrossRef]

14. Pérez-Lombard, L.; Ortiz, J.; Pout, C. A review on buildings energy consumption information. Energy Build. 2008, 40, 394-398. [CrossRef]

15. Muhaisen, A.S.; Gadi, M.B. Mathematical model for calculating the shaded and sunlit areas in a circular courtyard geometry. Build. Environ. 2005, 40, 1619-1625. [CrossRef]

16. Department of Energy. Energy Solutions Lower Operating Costs, Boost Productivity. Available online: http://www.Eere.Energy.Gov/buildings (accessed on 16 August 2004).

17. Ekkachi, M. Solar Effective Envelop Design Advisor. Ph.D. Thesis, Department of Architecture, Illinois Institute of Technology, Chicago, IL, USA, 2003.

18. Gratia, E.; de Herde, A. Design of low energy office buildings. Energy Build. 2003, 35, 473-491. [CrossRef]

19. Aldawoud, A. The influence of the atrium geometry on the building energy performance. Energy Build. 2013, 57, 1-5. [CrossRef]

20. Barthakur, A. Behavior of Atria: A Comparative Study between Measured Data and a Computational Fluid Dynamics Model. Master's Thesis, University of Southern California, Los Angeles, CA, USA, 1996.

21. Bajracharya, S. Computer Simulation of Thermal Behavior of Atriums. Master's Thesis, Department of Mechanical Engineering, University of Calgary, Calgary, AB, Canada, 1997.

22. Atif, M.R. Top-glazed public spaces: Amenities, energy costs and indoor environment. Constr. Can. 1994, 36, 43-47.

23. Mills, F. Atrium Buildings: Architecture and Engineering; Construction Industry Conference Centre Ltd.: Welwyn, UK, 1991; pp. 13-22.

24. Muhaisen, A.S.; Gadi, M.B. Effect of courtyard proportions on solar heat gain and energy requirement in the temperate climate of rome. Build. Environ. 2006, 41, 245-253. [CrossRef]

25. Muhaisen, A.S.; Gadi, M.B. Shading performance of polygonal courtyard forms. Build. Environ. 2006, 41, 1050-1059. [CrossRef]

26. Muhaisen, A.S. Shading simulation of the courtyard form in different climatic regions. Build. Environ. 2006, 41, 1731-1741. [CrossRef]

27. Kocagil, I.E.; Oral, G.K. The effect of building form and settlement texture on energy efficiency for hot dry climate zone in turkey. Energy Procedia 2015, 78, 1835-1840. [CrossRef]

28. Manioğlu, G.; Oral, G.K. Effect of courtyard shape factor on heating and cooling energy loads in hot-dry climatic zone. Energy Procedia 2015, 78, 2100-2105. [CrossRef]

29. Horan, J.M.; Finn, D.P. Sensitivity of air change rates in a naturally ventilated atrium space subject to variations in external wind speed and direction. Energy Build. 2008, 40, 1577-1585. [CrossRef] 
30. Yaşa, E.; Ok, V. Evaluation of the effects of courtyard building shapes on solar heat gains and energy efficiency according to different climatic regions. Energy Build. 2014, 73, 192-199. [CrossRef]

31. Ok, V.; Yasa, E.; Özgunler, M. An experimental study of the effects of surface openings on air flow caused by wind in courtyard buildings. Archit. Sci. Rev. 2008, 51, 263-268. [CrossRef]

32. Laouadi, A.; Atif, M.; Galasiu, A. Towards developing skylight design tools for thermal and energy performance of atriums in cold climates. Build. Environ. 2002, 37, 1289-1316. [CrossRef]

33. Galasiu, A.D.; Atif, M.R. Applicability of daylighting computer modeling in real case studies: Comparison between measured and simulated daylight availability and lighting consumption. Build. Environ. 2002, 37, 363-377. [CrossRef]

34. Haw, L.C.; Saadatian, O.; Sulaiman, M.Y.; Mat, S.; Sopian, K. Empirical study of a wind-induced natural ventilation tower under hot and humid climatic conditions. Energy Build. 2012, 52, 28-38. [CrossRef]

35. Lin, J.-T.; Chuah, Y.K. A study on the potential of natural ventilation and cooling for large spaces in subtropical climatic regions. Build. Environ. 2011, 46, 89-97. [CrossRef]

36. Liu, P.-C.; Lin, H.-T.; Chou, J.-H. Evaluation of buoyancy-driven ventilation in atrium buildings using computational fluid dynamics and reduced-scale air model. Build. Environ. 2009, 44, 1970-1979. [CrossRef]

37. Karava, P.; Athienitis, A.; Stathopoulos, T.; Mouriki, E. Experimental study of the thermal performance of a large institutional building with mixed-mode cooling and hybrid ventilation. Build. Environ. 2012, 57, 313-326. [CrossRef]

38. Woods, A.W.; Fitzgerald, S.; Livermore, S. A comparison of winter pre-heating requirements for natural displacement and natural mixing ventilation. Energy Build. 2009, 41, 1306-1312. [CrossRef]

39. Göçer, Ö.; Tavil, A.; Özkan, E. Thermal performance simulation of an atrium building. In Proceedings of the eSim Building Performance Simulation Conference, University of Toronto, Toronto, ON, Canada, 4-5 May 2006.

40. Abdullah, A.H.; Meng, Q.; Zhao, L.; Wang, F. Field study on indoor thermal environment in an atrium in tropical climates. Build. Environ. 2009, 44, 431-436. [CrossRef]

41. Laouadi, A.; Atif, M.R. Comparison between computed and field measured thermal parameters in an atrium building. Build. Environ. 1998, 34, 129-138. [CrossRef]

42. De Luis, F.; Pérez-García, M. Parametric study of solar gains in saw-tooth roofs facing the equator. Renew. Energy 2004, 29, 1223-1241. [CrossRef]

43. Shpuza, E. Floorplate Shapes and Office Layouts: A Model of the Effect of Floorplate Shape on Circulation Integration; Citeseer: Atlanta, GA, USA, 2006.

44. Kim, G.; Kim, J.T. Luminous impact of balcony floor at atrium spaces with different well geometries. Build. Environ. 2010, 45, 304-310. [CrossRef]

45. Du, J.; Sharples, S. Assessing and predicting average daylight factors of adjoining spaces in atrium buildings under overcast sky. Build. Environ. 2011, 46, 2142-2152. [CrossRef]

46. Al-Masri, N.; Abu-Hijleh, B. Courtyard housing in midrise buildings: An environmental assessment in hot-arid climate. Renew. Sustain. Energy Rev. 2012, 16, 1892-1898. [CrossRef]

47. Cantón, M.A.; Ganem, C.; Barea, G.; Llano, J.F. Courtyards as a passive strategy in semi dry areas. Assessment of summer energy and thermal conditions in a refurbished school building. Renew. Energy 2014, 69, 437-446. [CrossRef]

48. Henninger, R.H.; Witte, M.J. Energyplus Testing with Ansi/Ashrae Standard 140-2001 (Bestest) Energyplus Version 1.1.0.020; Ernest Orlando Lawrence Berkeley National Laboratory Berkeley, California, for U.S. Department of Energy: Berkeley, CA, USA, 2004.

49. Designbuilder Software Homepage. Available online: http://www.Designbuilder.Co.Uk. (accessed on 10 January 2015).

50. Maile, T.; Fischer, M.; Bazjanac, V. Building energy performance simulation tools-a life-cycle and interoperable perspective. Cent. Integr. Facil. Eng. CIFE Work. Pap. 2007, 107, 1-49.

51. Crawley, D.B.; Hand, J.W.; Kummert, M.; Griffith, B.T. Contrasting the capabilities of building energy performance simulation programs. Build. Environ. 2008, 43, 661-673. [CrossRef]

52. Radhi, H. On the optimal selection of wall cladding system to reduce direct and indirect $\mathrm{CO}_{2}$ emissions. Energy 2010, 35, 1412-1424. [CrossRef]

53. Climate Data Homepage. Available online: http:/ / en.Climate-data.Org/region/ (accessed on 10 January 2015). 
54. Ko, D.H.; Elnimeiri, M.; Clark, R.J. Assessment and prediction of daylight performance in high-rise office buildings. Struct. Des. Tall Spec. Build. 2008, 17, 953-976. [CrossRef]

55. Cho, J. A study of form composition and efficiency in high-rise office buildings. J. Archit. Inst. Korea 2007, 23, 33-40.

56. Ts825, Turkish Standard, Thermal Insulation Requirements for Building. Available online: http://www.detic. $\mathrm{eu} /$ placeholders/documents/activity/binalar_icin_termal_izolasyon_gereklilikleri_turk_standartlari.pdf (accessed on 29 April 2016).

57. Aldawoud, A.; Clark, R. Comparative analysis of energy performance between courtyard and atrium in buildings. Energy Build. 2008, 40, 209-214. [CrossRef]

(C) 2016 by the authors; licensee MDPI, Basel, Switzerland. This article is an open access article distributed under the terms and conditions of the Creative Commons Attribution (CC-BY) license (http://creativecommons.org/licenses/by/4.0/). 